\title{
Changes in prevalence of and attitudes to restrictions on smoking in the workplace among indoor workers in the state of Victoria, Australia, 1988-90
}

Ron Borland

\begin{abstract}
Objective To monitor change in the prevalence of, distribution of, and attitudes to smoking restrictions among a representative sample of indoor workers in Victoria, Australia.

Methods Three cross sectional community samples of indoor workers were collected in 1988, 1989, and $1990(\mathrm{n}=975$, 1027, and 933). They were interviewed about attitudes to workplace smoking bans and the extent of restrictions, if any, to which they were subject.

Results The percentage of indoor workers reporting a total workplace smoking ban increased from $17 \%$ to $33 \%$ $(p<0.0001)$. There were no differences in rate of change as a function of type of work (white or blue collar) or type of employer. Attitudes to bans became more positive $(\mathbf{p}<0.0001)$ over the same period in that more people preferred a total workplace ban. Preferences were strongly associated with actual restrictions $(\mathbf{p}<0.0001)$. Conclusions Total workplace smoking bans are becoming more prevalent and more likely to be preferred by workers and are thus an acceptable means of protecting workers from exposure to environmental tobacco smoke.
\end{abstract}

\section{Introduction}

There is now a large body of research demonstrating links between passive smoking and a range of illnesses..$^{1-3}$ The Australian Federal Court recently found that the evidence constituted proof that passive smoking could harm the health of non-smokers. ${ }^{4}$ There are now a range of moves to restrict smoking in enclosed spaces. Smoking is now restricted at least in some countries in areas such as on public transport, on domestic airlines, in cinemas, and in government buildings. However, outside of the home, the workplace is the place where people spend most time and is thus the place where potential exposure to passive smoking is greatest. Increasing scientific evidence and judicial findings are likely to increase the pressure on employers to implement total bans on smoking.
Within Australia pressure for total bans on smoking in the workplace has occurred in the context of occupational health and safety legislation which mandates a safe and healthy workplace. Concern about litigation under this legislation is a major factor leading employers to adopt workplace smoking bans. There are also strong campaigns for tobacco control throughout Australia. In Victoria there is a strong, well funded (about A $\$ 1$ or 80 US cents per head of population) comprehensive health promotion programme for tobacco control. This programme uses a combination of mass media, community (including workplaces), and individual support programmes; it also works for appropriate changes in social policy and legislation.

Restrictions on smoking in workplaces and other public places are increasingly supported by the Australian public. ${ }^{56}$ In the state of Victoria some support for employers implementing bans has been provided by the Victorian Smoking and Health Program, the major tobacco control organisation in the state. The support includes the availability of kits outlining the need for workplace bans and strategies for implementation. Self help cessation materials and facilitator led cessation programmes are also available and there are opportunities for training staff in how to implement such policies. These resources have been made widely available and have been used to varying degrees by large numbers of organisations. It is not known accurately to what extent they have been used during the process of implementation of smoking restrictions.

Among workers support for workplace smoking bans increases following the implementation of restrictions. ${ }^{7-12}$ Workplace smoking bans can result in a reduction in cigarette consumption among smokers ${ }^{9-14}$ and may result in increased smoking cessation. ${ }^{91214}$ As a consequence, workplace smoking bans have important health benefits for smokers as well as for non-smokers.

I reported that in 1988 almost two thirds of Victorian (Australia) indoor workers worked in workplaces with some restrictions on smoking, with nearly $17 \%$ of employees reporting being protected by a total smoking ban. ${ }^{15}$ This paper reports on two subsequent surveys using in Cancer, 1 Rathdowne Stree Carlton South, Victoria 305 Australia 
the same methods and compares the results with those already published.

The aims of this paper are, firstly, to obtain estimates of the prevalence of indoor workers reporting restrictions on smoking at their workplaces in Victoria, Australia, and to explore changes in the prevalence of those restrictions; secondly, to explore variations in restrictions as a function of characteristics of the workplaces in which these workers were employed, as well as to further explore sociodemographic variation in reported restrictions; and, thirdly, to explore the relation between the experience of bans or restrictions and beliefs about what level of restrictions should be imposed.

\section{Subjects and methods SUBJECTS}

Subjects were employed people from each of three household surveys who worked primarily indoors. Details of the samples can be found in table 1. There were no differences in the distributions of the samples as a function of age, sex, educational level, or occupational category (white collar versus blue collar).

\section{PROCEDURES}

The first survey was conducted from midOctober to mid-November $1988 .^{15}$ The subsequent two surveys were conducted from late September to late October 1989 and over a similar period in 1990. The same method of selecting subjects was used in all three surveys. Interviewing was always conducted at weekends. Sample selection was based on Commonwealth electoral subdivisions. Interviews were conducted face to face in the respondent's home. Only one respondent from each household was interviewed, selection being according to a predetermined formula based on age and sex. This sampling method gives a good representation of the population and has been used, among other things, to monitor the prevalence of smoking in Australia. ${ }^{16-18}$

The results reported here are from a series of questions that were part of a standard public

Table 1 Characteristics of the three samples. Values are percentages unless stated otherwise

\begin{tabular}{|c|c|c|c|}
\hline $\begin{array}{l}\text { Indoor workers: } \\
\% \text { of total sample... } \\
\text { No.... }\end{array}$ & $\begin{array}{r}1988 \\
43 \\
975\end{array}$ & $\begin{array}{r}1989 \\
44 \\
1027\end{array}$ & $\begin{array}{r}1990 \\
40 \\
933\end{array}$ \\
\hline \multicolumn{4}{|l|}{ Sex: } \\
\hline $\begin{array}{l}\text { Male } \\
\text { Female }\end{array}$ & $\begin{array}{l}48 \\
52\end{array}$ & $\begin{array}{l}49 \\
51\end{array}$ & $\begin{array}{l}50 \\
50\end{array}$ \\
\hline \multicolumn{4}{|l|}{ Age (years): } \\
\hline & $\begin{array}{l}36 \\
50\end{array}$ & $\begin{array}{l}33 \\
53\end{array}$ & $\begin{array}{l}34 \\
51\end{array}$ \\
\hline \multicolumn{4}{|l|}{ Smoking status: } \\
\hline $\begin{array}{l}\text { Smoker } \\
\text { Non-smoker }\end{array}$ & $\begin{array}{l}33 \\
67\end{array}$ & $\begin{array}{l}31 \\
69\end{array}$ & $\begin{array}{l}29 \\
71\end{array}$ \\
\hline \multicolumn{4}{|l|}{ Employment type: } \\
\hline $\begin{array}{l}\text { White collar } \\
\text { Blue collar }\end{array}$ & 64 & 60 & 60 \\
\hline \multicolumn{4}{|l|}{ Employer type: } \\
\hline $\begin{array}{l}\text { Public } \\
\text { Private } \\
\text { Self employed }\end{array}$ & $\begin{array}{r}29 \\
65 \\
6\end{array}$ & $\begin{array}{r}32 \\
63 \\
6\end{array}$ & $\begin{array}{r}30 \\
64 \\
6\end{array}$ \\
\hline
\end{tabular}

opinion survey which included a range of other questions about smoking and about awareness of and attitudes towards anti-smoking advertising as well as other material not related to smoking.

\section{QUESTIONS ASKED}

Early in the survey all respondents in the 1989 and 1990 surveys and half the respondents in the 1988 survey were asked to select an option that best described their belief about the level of restrictions on smoking that should be applied in the workplace from five response categories. The options were: (1) do not allow smoking anywhere at work; (2) allow in specific areas only during breaks; (3) allow in special areas anytime; (4) allow anywhere only during breaks; and (5) allow anywhere, anytime. For most analyses, categories 3 and 4 were combined into a lesser restrictions category. At a later point in the survey respondents were given a card describing a range of workplace smoking restrictions and asked to indicate which applied in their normal workplace. The options were: (1) a total ban on smoking; (2) a total ban everywhere except for a smoking room; (3) bans in some areas including where I normally work; (4) a ban in some areas but not where I normally work; and (5) no restrictions.

Sociodemographic data collected were age; sex; smoking status (non-smokers, current smokers); occupational category (blue collar, white collar); and employer type (public sector, private sector, self employed). In the third survey more detail was gathered about the nature of the workplace in which a person worked.

\section{ANALYSES}

Bivariate analyses between level of bans and the sociodemographic variables were computed using $\chi^{2}$ tests of significance for each of the three years. To explore interactions logistic regression was used.

For the multivariate analyses experienced level of restriction was recoded into three categories: total ban (1 above); major restrictions ( 2 and 3 above); and limited or no restrictions ( 4 and 5 above). Also, because of the small numbers of self employed workers, these cases were dropped from multivariate analyses including employment type.

\section{Results}

As can be seen from table 2, there was a marked shift towards a greater percentage of indoor workers reporting a total workplace smoking ban between 1988 and 1990, the proportion almost doubling $\left(\chi^{2}=71 \cdot 9, \mathrm{df}=2\right.$, $\mathrm{p}<0.0001)$ as part of a marked overall shift in the distribution of levels of restrictions $\left(\chi^{2}=\right.$ $96.4, \mathrm{df}=8, \mathrm{p}<0.0001$ ). This was mainly due to a reduction in the number of workers not protected by any restrictions between 1988 and 1989 and to a reduction in those protected $\because \frac{10}{20}$

ஓे

$y \%$

㲅

$>\frac{2}{\frac{\pi}{2}}$

。ำ

$+\mathscr{\infty}$

$\overrightarrow{0}$

$\overrightarrow{\vec{\omega}}$

ก

$+$

$+1$

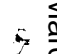

ก)

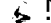

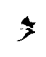

7

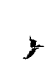

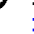


Table 2 Changes in distribution of restrictions on smoking in the workplace among indoor workers in Victoria, 1988-90. Values are percentages

\begin{tabular}{llll}
\hline & \multicolumn{2}{l}{ Year } & \\
\cline { 2 - 3 } Restriction & $\begin{array}{l}1988 \\
(n=975)\end{array}$ & $\begin{array}{l}1989 \\
(n=1027)\end{array}$ & $\begin{array}{l}1990 \\
(n=933)\end{array}$ \\
\hline Total ban & 17 & 28 & 33 \\
Smoking room & 23 & 23 & 23 \\
Areas where I work & 18 & 17 & 11 \\
Other areas & 7 & 7 & 7 \\
No restrictions & 35 & 24 & 25 \\
\hline
\end{tabular}

$\chi^{2}=96.4, \mathrm{df}=8, \mathrm{p}<0.0001$

by limited restrictions (but including their workstation) between 1989 and 1990 .

Bivariate analyses combining data from the three years surveyed showed that the extent of smoking restrictions was associated with sex, smoking status, job type, and employment type, but not with the age of respondents. The multivariate analyses showed that the sex effect was due to interactions between smoking status and employment type and it is not considered further. Details of the bivariate effects are reported in table 3 for 1990 data only. Overall, white collar workers were protected by restrictions more than blue collar workers. In 1988 there was no significant difference for this comparison, ${ }^{15}$ although there was a trend for greater restrictions among white collar workers. This trend was significant in the final two years, but there were no significant interactions between work type, year, and level of restrictions. Workers employed in the public sector were protected by restrictions more than those employed in the private sector or those who were self employed.

Smokers were more likely to report the existence of smoking rooms and limited restrictions allowing them to smoke where they worked than were non-smokers (table 3 ). In all cases there was no evidence of interactions between these variables, level of smoking restrictions, and year of survey.

One interaction between type of ban and sociodemographic variables was marginally significant; this was between employment type, employer type, and level of restrictions. White collar workers were more often protected by restrictions than blue collar workers, and this difference was greater among those working in the private sector compared with the public sector.

Apart from the strong relation between year and level of restrictions reported above, there were no interactions between the sociodemographic variables, year, and level of restrictions. As a result, because many readers are likely to be more interested in the more recent data, the 1990 data are presented, although the analyses for interactions between variables were conducted with the year of survey included as a variable. In table 3 data are represented on levels of restrictions as a function of smoking status, job type, and employer type.

In the 1990 survey the type of work environment was considered in more detail, breaking down the workplaces into the categories shown in table 4 . This table shows that the kinds of workplaces where blue collar workers are more prevalent were less likely to have extensive bans than the office, hospital, or school settings where white collar workers are more prevalent. It is not clear whether this merely reflects the differences in level of restrictions between blue and white collar workers reported above or whether it is one reason for the existence of the differences. It is also of interest to note that although restrictions are prevalent in hospitals, few seem to be totally smoke-free.

Analysis of the question on appropriate levels of restrictions shows that support for total bans has increased significantly $\left(\chi^{2}=\right.$ 53.9, df $=2, \mathrm{p}<0.0001)$, with an overall decline in support for lesser or no restrictions (table 5). We also explored the relation between the restrictions reported by indoor workers and attitudes to restrictions. The response options to the two items differ because the possibility of time based restrictions was included in the opinion question but not in the report of restriction levels. To make the two questions maximally compatible, the reported extent of restrictions was coded into four categories with categories 3 and 4 combined, and the desired restrictions variable was recoded similarly. As can be seen in table 6 , there was a strong relation such that respondents tended to support a level of restrictions that was similar to the level which they were actually experiencing. This shows that those workers protected by total workplace bans are most strongly in support of total bans.

\section{Discussion}

The results of these surveys indicate that the proportion of workers protected by workplace smoking bans has increased markedly in Victoria over the period 1988-90. Total bans are more prevalent and the proportion of

Table 3 Level of workplace restrictions as a function of smoking status, employment type, and employer type in 1990. Values are percentages

\begin{tabular}{|c|c|c|c|c|c|c|c|}
\hline & \multicolumn{2}{|c|}{ Smoking status } & \multicolumn{2}{|c|}{ Employment } & \multicolumn{3}{|l|}{ Employer } \\
\hline & $\begin{array}{l}\text { Smoker } \\
(n=272)\end{array}$ & $\begin{array}{l}\text { Non- } \\
\text { smoker } \\
(n=657)\end{array}$ & $\begin{array}{l}\text { White } \\
\text { collar } \\
(n=561)\end{array}$ & $\begin{array}{l}\text { Blue } \\
\text { collar } \\
(n=372)\end{array}$ & $\begin{array}{l}\text { Public } \\
\text { sector } \\
(n=281)\end{array}$ & $\begin{array}{l}\text { Private } \\
\text { sector } \\
(n=597)\end{array}$ & $\begin{array}{l}\text { Self } \\
\text { employed } \\
(n=55)\end{array}$ \\
\hline Total ban & 24 & 37 & 40 & 23 & 53 & 25 & 29 \\
\hline Smoking room & 24 & 23 & 22 & 25 & 30 & 22 & 9 \\
\hline Where I work & 13 & 11 & 10 & 13 & 7 & 14 & 6 \\
\hline Other areas & 10 & 6 & 6 & 9 & 4 & 9 & 4 \\
\hline No restrictions & 29 & 23 & 22 & 29 & 6 & 31 & 53 \\
\hline
\end{tabular}


Table 4 Types of workplaces by level of restrictions in 1990. Values are percentages

\begin{tabular}{llll}
\hline & $\begin{array}{l}\text { Total } \\
\text { ban }\end{array}$ & $\begin{array}{l}\text { Major } \\
\text { restrictions }\end{array}$ & $\begin{array}{l}\text { Limited } \\
\text { or no } \\
\text { restrictions }\end{array}$ \\
\hline Warehouse/factory, etc $(\mathrm{n}=172)$ & 10 & 33 & 57 \\
Shop, supermarket, etc $(\mathrm{n}=98)$ & 34 & 43 & 24 \\
Open plan office $(\mathrm{n}=296)$ & 38 & 31 & 31 \\
Separate office $(\mathrm{n}=118)$ & 38 & 26 & 36 \\
School $(\mathrm{n}=83)$ & 64 & 29 & 7 \\
Hospital $(\mathrm{n}=75)$ & 27 & 67 & 7 \\
Other $(\mathrm{n}=91)$ & 33 & 33 & 34 \\
\hline
\end{tabular}

Table 5 Desired level of workplace restrictions in 1988-90. Values are percentages

\begin{tabular}{llll}
\hline & \multicolumn{3}{l}{ Year } \\
\cline { 2 - 4 } $\begin{array}{l}\text { Desired level } \\
\text { of restrictions }\end{array}$ & $\begin{array}{l}1988 \\
(n=465) \star\end{array}$ & $\begin{array}{l}1989 \\
(n=1027)\end{array}$ & $\begin{array}{l}1990 \\
(n=937)\end{array}$ \\
\hline $\begin{array}{l}\text { No smoking anywhere } \\
\text { Special areas in breaks }\end{array}$ & 14 & 26 & 32 \\
Special areas anytime & 46 & 41 & 37 \\
Anywhere but only in breaks & 23 & 22 & 19 \\
No restrictions & 11 & 4 & 6 \\
\hline
\end{tabular}

$\chi^{2}=64 \cdot 1, \mathrm{df}=8, \mathrm{p}<0.0001$

$\star$ Only half the respondents in 1988 were asked about desired level of restrictions.

Table 6 Desired level of workplace restrictions by actual restrictions people were subject to. Values are percentages

\begin{tabular}{lllll}
\hline & \multicolumn{2}{l}{ Level of restrictions } \\
\cline { 2 - 5 } $\begin{array}{l}\text { Dotal } \\
\text { Desired level }\end{array}$ & $\begin{array}{l}\text { Smoking } \\
\text { of restrictions }\end{array}$ & $\begin{array}{l}\text { Lesser } \\
\text { room } \\
(n=310)\end{array}$ & $\begin{array}{l}\text { Nostrictions } \\
(n=174)\end{array}$ & $\begin{array}{l}\text { Nostrictions } \\
(n=229)\end{array}$ \\
\hline No smoking anywhere & 52 & 20 & 20 & 26 \\
Special areas in breaks & 29 & 51 & 38 & 33 \\
Lesser restrictions & 17 & 26 & 37 & 26 \\
No restrictions & 2 & 3 & 5 & 15 \\
\hline
\end{tabular}

$\chi^{2}=137.89 ; \mathrm{df}=9, \mathrm{p}<0.0001$

workers who are not protected by any form of restriction has declined. Though public sector and white collar employees are more often protected by bans, changes have occurred across all sectors of the workforce and those changes are of a similar magnitude. The finding that public sector workers were more likely to report restrictions on smoking than private sector employees differs from data from Texas, where reported levels of smoking policies were similar among private and public sector organisations. ${ }^{19}$ This difference suggests that the distribution of workplace restrictions by employment type may vary as a function of aspects of the social context. In Australia centralised health promotion agencies have applied a lot of pressure on public sector organisations to go smoke-free.

The finding that workers protected by total bans are more likely to believe that total bans are the most desirable form of workplace restriction is consistent with results of a longitudinal study about the implementation of bans, which found that workers became more accepting of bans once they were implemented. ${ }^{7}$ This further confirms that the introduction of workplace smoking bans are generally acceptable to staff.

The data reported in this paper are on what workers perceive as the restrictions at their workplace. This will not always correspond with employer policies. Apart from respondent error, there will be cases where policies are violated and others where employee defined restrictions occur without employer policies. Policies of total bans are sometimes violated. In one study we found around one third of employees reported some smoking in the workplace in the context where there was a total ban. ${ }^{8}$ However, this does not mean that the self report measures underestimate the prevalence of policies. There is evidence to suggest that the levels of the two are closely aligned, at least among larger workplaces. A survey in early 1991 of large companies in Victoria found that one third of companies had a total smoking ban policy and only $15 \%$ had no, or virtually no restrictions ( $R$ Mullins, Victorian Smoking and Health Program, unpublished report). These findings are consistent with the results reported here. The unpublished report by Mullins for the Victorian Smoking and Health Program found that many companies are taking action to introduce or strengthen existing policy, so the proportion of workers protected by workplace smoking restrictions is expected to increase further.

The differences in the level of workplace restrictions across different sectors of the workforce warrants comment. Blue collar workers in the private sector are least likely to be protected by having a policy of workplace smoking restrictions. Whether this is because there are more smokers in this group, whether they are more resistant to change, or whether it is because management consider some areas used by blue collar employees to be less in need of smoking restrictions is not known. There is some support for the last of these possibilities - some employers consider that large factories and warehouses allow smoke to dissipate at a similar rate to that outdoors, obviating the need for restrictions ( $\mathrm{R}$ Mullins, unpublished report). Alternatively, subjective standards as to what constitutes clean air may be less stringent in such places as they are traditionally dustier than offices. That there are more smokers, and thus more potential resistance to restrictions, may not be the most important factor as the relation between prevalence of restrictions and smoking status is weaker than that for characteristics of the work environment. However, where support for smokers to adapt to restrictions is not adequate, the proportion of smokers in a workplace might affect compliance.

The results of these surveys should provide further reassurance to managers who are considering implementing a workplace smoking ban and to staff who are lobbying for its introduction. A total workplace ban is becoming more common, workers are now more likely to expect this, and once it is instituted it becomes more accepted by workers, including among some smokers who may previously have resisted its introduction. If the current trends continue, a majority of indoor workers in Victoria might be protected by a total workplace smoking ban within two or three years.

The results show that, at least in an industrial- 
ised nation with a strong public smoking control programme, moves towards smokefree workplaces can proceed quickly and be acceptable to most of the staff involved. Little is known about progress towards smoke-free workplaces in other places. Workplace restrictions are also quite prevalent in South Australia ${ }^{20}$ and in the United States, where other representative samples have been surveyed. ${ }^{192122}$ The experience from most places where bans have been implemented seems to be that they are generally accepted by employees.

This research was funded by the Victorian Smoking and Health Program through a grant from the Victorian Health Promotion Program through a grant from the Victorian Health Promotion constructive comments on an earlier version of the manuscript.

1 National Health and Medical Research Council. Effects of passive smoking on health. Report of NH and MRC passive smoking on health. Australian Government Publishing Service, 1986.

2 United States Department of Health and Human Services. The health consequences of involuntary smoking: a report of the Surgeon General.

3 Glantz SA, Parmley WW. Passive smoking and heart disease: epidemiology, physiology and biochemistry. Circulation 1991; 83: 1-12.

4 Everingham $\mathrm{R}$, Woodward $\mathrm{S}$, eds. Tobacco litigation. $A F C O$ v TIA: the case against passive smoking. Sydney: Legal Books, 1991.

5 Hill D. Public opinion about smoking in restaurants and at work. Med 7 Aust 1986; 145 : 657-8.

6 Borland R, Naccarella L. Public opinion about regulation of smoking to protect others. Melbourne: Victorian Smoking smoking to protect others. Melbourne: Victorian Smoking and Health Program, 1991. Victorian 5 .

7 Borland R, Owen N, Hill D, Chapman S. Changes in acceptance of workplace smoking bans following their acceptance of workplace smoking bans following their implementa 22 .
8 Hocking B, Borland R, Owen N, Kemp G. A total ban on workplace smoking is acceptable and effective. $\mathcal{F}$ Occup workplace smoking is

9 Stillman FA, Becker DM, Swank RT, Hantula D, Moses N, Glantz S, Waranch HR. Ending smoking at the Johns Hopkins medical institutions: an evaluation of smoking prevalence and indoor air pollution. $\mathscr{F} A M A 1990 ; 264$ 1565-9.

10 Biener L, Abrams DB, Follick MJ, Dean L. A comparative evaluation of a restrictive smoking policy in a general hospital. Am f Public Health 1989; 79: 192-5.

11 Gottlieb N, Erickson M, Lovato C, Weinstein F, Green L. Impact of a restrictive worksite smoking policy on smoking behaviour,

12 Petersen LR, Helgerson SD, Gibbons CM, Calhoun CR, Ctere $\mathrm{KH}$, Pitchero $\mathrm{KC}$, changes and attitudes following a restrictive policy on worksite smoking in

13 Borland R, Chapman S, Owen N, Hill D. Effects of workplace smoking bans on cigarette consumption. $A m \mathcal{F}$ Public Health 1990; 80: 178-80.

14 Borland R, Owen N, Hocking B. Changes in smoking behaviour following the implementation of a total workplace smoking ban. Australian fournal of Public Health 1991; 15: 130-4.

15 Borland $\mathbf{R}$. The extent of restrictions on smoking in the workplace. Fournal of Occupational Health and Safety of Australia and New Zealand 1990; 6: 93-6.

16 Hill DJ, Gray NJ. Australian patterns of tobacco smoking and related health beliefs in 1983. Community Health Stud 1984; 8: 307-16.

17 Hill DJ, White VM, Gray NJ. Measure of tobacco smoking in Australia 1974-1986 by means of a standard method. in Australia 1974-1986 by mean

18 Hill DJ, White VM, Gray NJ. Australian patterns of tobacco smoking in 1989. Med $\mathscr{f}$ Aust $1991 ; 154: 797-801$.

19 Gottlieb NH, Hedl JJ Jr, Eriksen MP, Chan F. Smoking policies among private employers and public agencies in Texas: a statewide analysis. $\mathcal{F} N C I 1989 ; 81: 200-4$.

20 Wakefield MA, Wilson D, Owen N, Esterman A, Roberts L. Workplace smoking restrictions, occupational status and reduced cigarette consumption. F Occup Med (in press).

21 Bureau of National Affairs. Smoking in the workplace: 1991. Bulletin to management. Washington, DC: Bureau of National Affairs, 1991. (BNA Policy and Practice Series. SHRM and BNA Survey No 55 .)

22 Rigotti NA, Pashos CL. No-smoking laws in the United States: an analysis of state and city actions to limit smoking in public places and workplaces. $\mathscr{f} A M A 1991$; 266: 3162-7. 


\section{Translations \\ of abstract}

Généralisation des restrictions du tabagisme sur les lieux du travail et attitudes des travailleurs en lieux clos face à ces restrictions dans l'état de Victoria, Australie, 1988-90

Ron Borland

Résumé

Objectif: Observer la généralisation, la répartition et les réactions face aux restrictions du tabagisme parmi un échantillon représentatif de travailleurs à Victoria, Australie.

Méthodes: Trois groupes représentatifs des différentes catégories socio-professionnelles de travailleurs en lieux clos ont été sélectionnés en 1988, 1989 et 1990 $(\mathbf{n}=975,1027$ et 933 ). Les questions portaient sur leurs réactions face aux interdictions de fumer sur les lieux de travail ainsi que sur l'éventuelle existence et la description des restrictions appliquées.

Résultats: Le pourcentage des travailleurs en lieux clos qui ont mentionné une interdiction totale de fumer sur leur lieux de travail est passé de $17 \%$ à $33 \%$ (p < $0.0001)$. Aucune différence n'a été notée dans les taux calculés en fonction du type de travail (employé ou ouvrier) ou du type d'employeur. Au cours de la même période, les réactions face aux interdictions sont devenues plus positives $(p<0.0001)$, et un nombre croissant de personnes seraient favorables à une interdiction totale sur les lieux du travail. Les préférences ont été fortement associées avec les restrictions existantes $(\mathbf{p}<0.0001)$.

Conclusions: Les interdictions totales de fumer sur les lieux de travail se généralisent, et ce à la satisfaction croissante du travailleur; elles représentent donc un bon moyen de protéger les travailleurs contre l'exposition à la fumée de tabac dans l'air ambiant.
Cambios en la prevalencia y en las actitudes con respecto a las restricciones al tabaquismo en los lugares de trabajo entre los trabajadores en ambientes cerrados, en el estado de Victoria, Australia, 1988-90

Ron Borland

\section{Resumen}

Objetivo: Vigilar los cambios en la prevalencia, la distribución y las actitudes a las restricciones sobre el tabaquismo en una muestra representativa de trabajadores en ambientes cerrados en Victoria, Australia. Métodos: Tres muestras transversales de la comunidad de trabajadores en ambientes cerrados se recogieron en 1988,1989 y $1990(n=975,1027$ y 933). Las personas fueron entrevistadas acerca de las actitudes ante las prohibiciones de fumar en los lugares de trabajo y a la amplitud de las restricciones, si las había, a las que estuvieron sometidas.

Resultados: El porcentaje de los trabajadores en ambientes cerrados que notificaron una prohibición de fumar en el sitio de trabajo aumentó de $17 \%$ a $33 \%$ $(p<0.0001)$. No hubo diferencia en la tasa de variación como función del tipo de trabaja (trabajador manual o intelectual) o por tipo de patrono. Las actitudes ante las prohibiciones se tornaron más positivas $(p<0.0001)$ en el mismo periodo en que un mayor número de personas prefería una prohibición total de fumar en el sitio de trabajo. Las preferencias estaban marcadamente asociadas con restricciones concretas $(p<0.0001)$.

Conclusiones: Las prohibiciones totales de fumar en los lugares de trabajo están predominando cada vez más y tienen mayores probabilidades de ser bien recibidas por los trabajadores y, son, por lo tanto, un medio aceptable de protegerlos de la exposición al humo de tabaco ambiental.

\section{在工作场所限制吸烟的比率和室内工人对限制吸烟政策态度的变化 (1988-1990這大利亚維各利亚洲) \\ 罗纳・保兰德}

目标: 监测利亚维多利亚州室内工人的抽样人释, 分析在工作场所限制吸姻的比率和分 布，以及室内工人对在工作场所限制吸烟政策的态度。

方法: 分别于 1988、1989 和 1990 年运用以社区为单位的整群抽样方法调查公内工人对在工 作场所限制吸烟的态度以及他们受限制的程度，三次抽样调查的样本数依次为: 975 人、1027 人和 933 人.

纯果: 室内工人报告在工作场所慗止吸姻的比率从 $17 \%$ 上升到 $33 \%(\mathrm{P}<0.0001)$. 不同雇 主及不同工种（蓝领或白领）之间的禁烟变化市无显著差异. 成在工作场所祭止吸烟的人 越多则同期对等止吸烟的态度就越强烈 $(\mathrm{P}<0.0001)$. 算同程度与实际隄制吸姻程度有密切关 联 $(\mathrm{P}<0.0001)$.

结论: 在工作场所等止吸烟止越来越普遗，并且越来越受到工人的欢迎，因此在工作场所等 止吸烟以使工人免受被动吸烟之害的方法是切实可行的. 